UDC 65.012.65

JEL Classification: M1

http://doi.org/10.21272/mmi.2018.4-32

Jacek Strojny,

D.Sc., Associate Professor, Rzeszow University of Technology, Poland

Agnieszka Jedrusik,

D.Sc., Associate Professor, Rzeszow University of Technology, Poland

\title{
STAKEHOLDER ANALYSIS DURING A REORGANIZATION PROJECT IN LOCAL GOVERNMENT INSTITUTIONS - KEY METHODOLOGICAL ASPECTS
}

Abstract. Stakeholder analysis is one of the important elements of the management of every project. Particularly, it is a significant aspect in high-risk projects, e.g. reorganization. The concerns of different groups of workers, the impact of the project on suppliers or clients - these are not only potential sources of risk but opportunity as well. The success of the reorganization project is therefore likely determined by the quality of the stakeholder analysis. It is determined by many factors. One of them is the use of appropriate techniques of stakeholder analysis. In the literature, there are some proposals based on the general approaches to project management (e.g. IPMA ICB 4.0). Mostly they use a simple procedure of assessment of stakeholder's significance. Meanwhile, in many risky, a deeper reflection is needed. In these cases, a procedure of stakeholder analysis could be based on some decision-making methods. For this reason, the main aim of this article was chosen. That is, to identify the basic methodological assumptions of the process of stakeholder analysis which contains stages characteristic of a complex decision process. The proposed method was created and used in a study to provide a stakeholder analysis in one of the local governments in Poland on the occasion of the preparation of the reorganization project. Realizing the stated goal, a short literature review was provided in terms of the stakeholder activity and steps of stakeholders analysis. Then a new methodology of stakeholders analysis was proposed. For stakeholder identification and structuration, a procedure of the AHP method (Analytic Hierarchy Process) was used. This method was a basis for the analysis of stakeholder significance as well (using a Saaty's scale). There were proposed new scales for assessing the consistency of stakeholder's expectations with the project goals as well as the influence of the stakeholder on the project. This, the new methodology was verified during a real reorganization project in one of the Polish local governments. It is characterized by a higher workloadall the process of stakeholder analysis needs a group decision-making process. Moreover, members of the project team should have competences in the AHP method. The analysis is much more accurate. It allows for more accurate identification of stakeholders and understanding of their role in the project.

Keywords: reorganization project, stakeholder analysis, task-oriented organization, local government, public management.

Introduction. The condition for lifting, or even maintaining the competitiveness of the organization is constantly changing [1]. The environment is complex and dynamic in a global economy [2]. Processes occurring nowadays, make it necessary to improve the organization itself - its structure, organizational culture, IT technologies, management procedures, etc. Reorganization projects are therefore an important part of the activity of modern organizations, regardless of the sector in which they operate [3]. The literature emphasizes that the problem of raising competitiveness applies not only to the private sector but also to public institutions responsible for the development of territorial units [4]. They should change, adapting their behaviour to current and future development challenges. The reorganization project is the kind of activity that is exposed to a particularly high risk of negative feedback from stakeholders. The phenomenon of resistance to change is typical and observed with different intensity in every project of this type, and in every organization [5]. Public sector institutions, however, differ from private companies. They are usually more formal and bureaucratic, and employees are more conservative and more afraid of change [6]. A stakeholder analysis should, therefore, be conducted when reorganizing these types of entities, with special attention paid to the quality of the whole process.

Cite as: Strojny, J. \& Jedrusik, A. (2018). Stakeholder Analysis During a Reorganization Project in Local Government Institutions - Key Methodological Aspects. Marketing and Management of Innovations, 4, 372-381. http://doi.org/10.21272/mmi.2018.4-32 
The information obtained can significantly redefine the space of decision-making. Authorities of the institution, as well as the project manager responsible for the reorganization, can significantly reach their point of view on the project by understanding the stakeholders' expectations. Thanks to this, possible threats and opportunities are more visible and different scenarios for the project can be created. The process of stakeholder analysis should, therefore, be embedded in the context of the progress of the project and its various phases. The information obtained and drawn on the basis of the conclusions is, in fact, the foundation of actions that must be an integral part of the project. They should lead to a weakening of the negative influences and support the positive impact of stakeholders. The consequence of stakeholder analysis is, therefore, an action plan covering the schedule, resources, and an adequate budget. The planned reaction on stakeholders' needs should be reviewed and possibly adjusted throughout the course of the project. Stakeholder analysis is, therefore, an ongoing process and should be carried out not only during the stages of project preparation but also during its implementation.

The purpose of this article is to present the overall assumptions of the design of the process of stakeholder analysis. In pursuing this goal, a brief review of the literature was made regarding both - the role of stakeholders in the project, and the specificity of reorganization projects. Next, the methodological assumptions of the study are presented. They constituted the foundation of the research process focused on the verification of the proposed methodology. The study was conducted during the preparation of the reorganization project conducted in one of the local governments in Poland. The role of stakeholders in the realization of reorganization projects. The paper focuses on a specific type of activity of the organization, which in the literature is referred to as a project. These types of undertakings are understood as one-off (unique) tasks, requiring separation of the overall activities of the organization in terms of scheduling, resource, budget, and most important responsibility. The aim is usually to produce unique effects (products, services) [7, 8]. In the literature, a number of categories of projects can be distinguished. The article focuses on a specific type, which is defined as a reorganization project. It involves the implementation of changes in the way the organization functions - its processes, structures, products, organizational culture, etc. $[9,10]$. These kinds of undertakings often have the characteristics of organizational innovation [11]. It is often associated with the implementation of a new method of managing business processes, original organization of work or novel types of relations with the environment [12].

Reorganization projects significantly determine the conditions of staff functioning which cause the phenomenon of resistance to change. It can be understood as a set of reactions of individuals or groups of employees aimed at blocking or limiting the change [13]. There are two types of resistance to change that can be encountered during reorganization projects [14]. The first type is an active resistance which means that employees initiate certain actions to block the project or change its scope. The second type is a passive resistance consisting of a lack of involvement of employees in the implementation of tasks. All projects, and thus reorganization, are realized in a specific environment, which can be broadly divided into two dimensions $[15,16]$. The first is internal environment (organization through which the project is implemented) and the second - external (closer and further surroundings of the organization). Changes in any of these dimensions of the environment can positively or negatively influence the course of the project. In the first case, we can mention occasions, while in the second, the threats (risks) [17]. Some of these positive or negative factors are due to the general processes occurring in the environment (e.g. macroeconomic phenomena, changes in law, development of the technology, etc.) [18]. Some other phenomena, which may determine the project, resulting from a reaction of those entities which are directly connected with the organization (outside or inside it). Here we could mention: the organization's employees, customers, suppliers, public institutions issuing certain decisions, etc.) [19]. Both of these types of factors should be analysed in a similar way - with regards to both: the direction of the impact (positive or negative), and the strength of the impact. In the case of general processes, the organization has limited capabilities to respond. However, the response to the impact of certain entities can be much 
more complex. Here there are some relational systems that allow direct interaction with each entity. This mechanism can be used during the reorganization project. A diagram of the relationship between the project and its surroundings is shown in Figure 1.

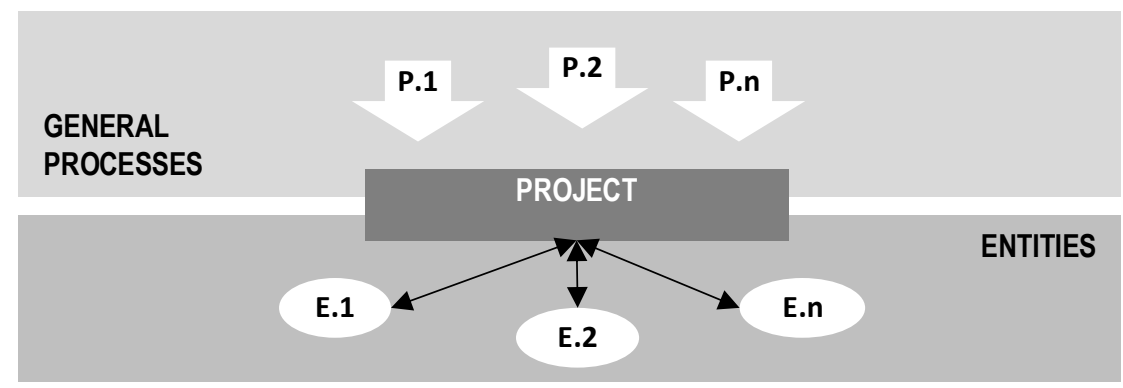

Figure 1 - Buyers and sellers of local product

Sources: developed by the authors

Therefore, in the frameworks of the environmental analysis, it is justified to extract the stakeholder analysis. This term refers to a set of activities involving the identification and assessment of the relationship between the project and the entities functioning in the organization and its surroundings. The concept of stakeholder is widely used in the science of management. It appears both in the context of strategic management [20], the policy of corporate social responsibility [21], and in project management as well [22]. In this paper, the stakeholder is understood as an entity (person, group of persons, organization), which is in some way connected with the project, e.g. determined by its outcomes or course. There is thus, a direct relationship between the stakeholder and the project [23]. The key to defining the role of stakeholders in the project is therefore to understand its expectations and the ways in which it can determine the project. In defining the relationship between the project and stakeholder, there is a need to describe the level of divergence or convergence between the objectives of the project and the expectations of stakeholders. This comparison can demonstrate whether there is a risk of conflict or an opportunity for cooperation with a stakeholder. This is the first dimension of stakeholders analysis, which can be defined as the compatibility level (Compatibility - C).

Table 1 - Classification of roles of stakeholders in the project

\begin{tabular}{|c|c|l|}
\hline Stakeholders & Symbol & \\
\hline $\begin{array}{c}\text { Real strong } \\
\text { allies }\end{array}$ & $S_{A_{R}}$ & $\begin{array}{l}\text { There is a clear compatibility in their expectations with the objectives of the project, they are } \\
\text { ready to cooperate and have the proper instruments to support the project }\end{array}$ \\
\hline Real weak allies & $\boldsymbol{W} \boldsymbol{A}_{\mathbf{R}}$ & $\begin{array}{l}\text { There is a clear compatibility in their expectations with the objectives of the project, they are } \\
\text { ready to cooperate, but do not have the instruments to support the project }\end{array}$ \\
\hline $\begin{array}{c}\text { Neutral } \\
\text { stakeholders }\end{array}$ & $\boldsymbol{N S}$ & $\begin{array}{l}\text { There is a weak convergence or divergence between their expectations and the objectives of } \\
\text { the project, which lowers the likelihood of their activity }\end{array}$ \\
\hline $\begin{array}{c}\text { Real weak } \\
\text { opponents }\end{array}$ & $\boldsymbol{W} \boldsymbol{O}_{\mathbf{R}}$ & $\begin{array}{l}\text { There is an incompatibility in their expectations with the objectives of the project, they are ready } \\
\text { to confront, but do not have the instruments to act }\end{array}$ \\
\hline $\begin{array}{c}\text { Real strong } \\
\text { opponents }\end{array}$ & $\boldsymbol{S O}_{\mathbf{R}}$ & $\begin{array}{l}\text { There is an incompatibility in their expectations with the objectives of the project, they are ready } \\
\text { to confront and have the instruments to act }\end{array}$ \\
\hline
\end{tabular}

Sources: developed by the authors

Yet, there is another dimension associated with the assessment of tools by which stakeholders can influence the course of the project and its subsequent effects (Tools - T). These tools can result from a 
variety of attributes of impact on the project, e.g. the availability of resources, decision-making powers, participation in the processes of the project, etc. In either case, an important element to be evaluated is the tendency of the stakeholder to be active - the probability of operation (Probability - P). Given these dimensions of influence, stakeholders can be divided into several groups (Table 1).

The presented three-dimensional diagram is the starting point for further studies. The methodological assumptions of the stakeholders analysis presented in the next part of this paper have been constructed on the basis of it.

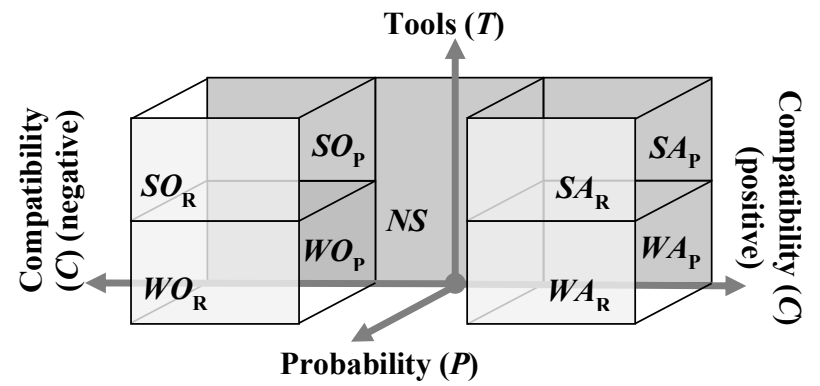

Figure 2 - Dimensions of the stakeholders analysis

Sources: developed by the author

The methodology of stakeholder analysis - basic assumptions and steps. Stakeholder identification, structure and description. The first step in stakeholder analysis is the identification, structuring and description of entities placed in the environment of the project. The approach characteristic for the Project Management method, involves the use of checklists of stakeholders, taking into account recognized ways of grouping. In order to improve this process, the use of the Analytic Hierarchy Process (AHP) method to create a Stakeholders Structure Model (SSM) is proposed. The AHP method is one of the world's most famous approaches to support decision-making. It was created in the 70 s by T. L. Saaty [24], and now is used not only in numerous scientific studies but also in the practice of management $[25,26]$.

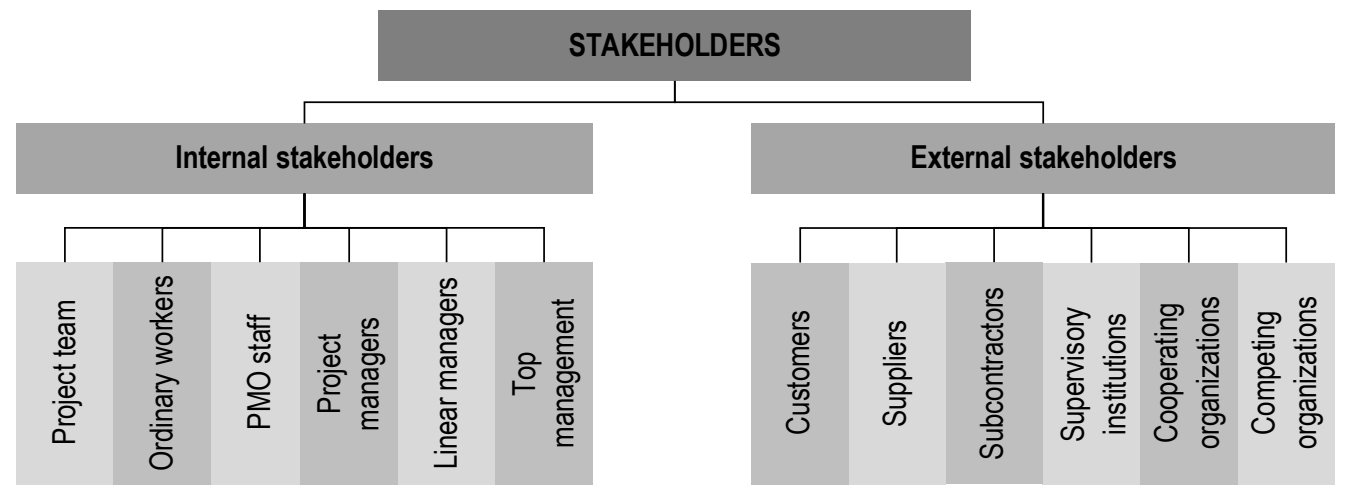

Figure 3 - General diagram of the Stakeholders Structure Model for reorganization project

Sources: developed by the author 
Thus, it was chosen to reach a new methodological approach for stakeholder analysis, that which is proposed in this paper. Based on the AHP method, the hierarchical model of typical stakeholders which can influence the reorganization project in different institutions, among others, in institutions of local government, was built, (Figure 3). In the proposed model, the main divisions of stakeholders (criteria level) are due to the separation of the internal and external environment of the organization. Thus, it distinguishes internal and external stakeholders. Within each of these two groups, the six detailed types of stakeholders were separated (sub-criteria level). Their short characteristics are shown in Table 2.

Table 2 - Characteristics of stakeholder groups

\begin{tabular}{|c|l|}
\hline Stakeholder & \multicolumn{1}{|c|}{ Internal stakeholders } \\
\hline \multicolumn{2}{|c|}{} \\
\hline Top management & An organization's top management, board members, council members \\
\hline Linear managers & $\begin{array}{l}\text { Line managers of the middle and lower level, affecting the project, disposing resources or } \\
\text { determined by the scope of the project }\end{array}$ \\
\hline Project managers & Managers of projects in the organization determined by the scope of the project \\
\hline PMO staff & $\begin{array}{l}\text { Employees of cell or cells supporting the project, leading the project controlling or determined by } \\
\text { its scope }\end{array}$ \\
\hline Ordinary workers & Ordinary workers working in the cell line or projects and determined by the scope of the project \\
\hline Project team & Members of the team carrying out the reorganization project \\
\hline \multicolumn{2}{|c|}{ External stakeholders } \\
\hline Customers & $\begin{array}{l}\text { Customer organizations, determined by the scope of the project, e.g. in terms of service quality, } \\
\text { offer structure or way of communication }\end{array}$ \\
\hline Suppliers & Organizations delivering products for the project or determined by its scope \\
\hline Subcontractors & Organizations providing services for the project or determined by its scope \\
\hline $\begin{array}{c}\text { Supervisory } \\
\text { institutions }\end{array}$ & $\begin{array}{l}\text { Institutions supervising the course of the project, issuing certain administrative decisions or } \\
\text { examining the compliance of the project with the law }\end{array}$ \\
\hline $\begin{array}{c}\text { Cooperating } \\
\text { organizations }\end{array}$ & Organisations involved in various projects implemented together with the audited organization \\
\hline $\begin{array}{c}\text { Competing } \\
\text { organizations }\end{array}$ & $\begin{array}{l}\text { Organizations competing with the audited organization in certain markets, in the case of local } \\
\text { government like the tourism market, human capital market or investment sources market }\end{array}$ \\
\hline
\end{tabular}

Sources: developed by the author

Each of the stakeholders can be characterized by one or more, from seven potential sources of power, building stakeholder influence on the course of the project (Table 3).

Table 3 - Sources of power of the stakeholder (tools of influence)

\begin{tabular}{|c|l|}
\hline Source of influence & \multicolumn{1}{|c|}{ Description } \\
\hline Assets control & Having by a stakeholder influence on the material resources needed for the project \\
\hline Knowledge control & $\begin{array}{l}\text { Having by a stakeholder a control of access to information, competence, and knowledge } \\
\text { which are necessary for project implementation }\end{array}$ \\
\hline Finance control & Having by a stakeholder a source of finances needed for the project \\
\hline People control & $\begin{array}{l}\text { Having by a stakeholder a control over an access to persons that are or may be involved to } \\
\text { the project }\end{array}$ \\
\hline Legal supervision & $\begin{array}{l}\text { Having by a stakeholder permission to issue certain permits or verifications on the legality of } \\
\text { actions taken within the framework of the project }\end{array}$ \\
\hline Personal attributes & $\begin{array}{l}\text { Having by a stakeholder individual features (like leadership) allowing an influence on the } \\
\text { behaviour of people in and outside the organization }\end{array}$ \\
\hline Participation in project & The degree to which the project's success depends on the quality of the stakeholder \\
\hline
\end{tabular}

Sources: developed by the author 
Analysis of stakeholder influence. The analysis of the impact of stakeholders on the project was carried out taking into account the three dimensions described above. For each of these, measures and measurement scales have been established according to the following scheme: Compatibility $-C \in\langle-5 ; 5\rangle$, Tools $-\mathrm{T} \in\langle 0 ; 5\rangle$, Probability $\mathrm{P} \in\langle 0 ; 5\rangle$. It was assumed that the impact of (Influence $-\mathrm{I}$ ) it is an indicator measured with regards to the above-mentioned dimensions. It may, therefore, be between $I \in\langle-125 ;+125\rangle$, calculated by the formula (1).

$$
1=C \times T \times P
$$

The first of these dimensions (Compatibility) requires the determination of the impact of a stakeholder in the project. It is assumed that in the case of compliance the direction is positive (support) when it comes to stakeholder expectations concerning the objectives of the project. However, in the case of non - the relation is negative (conflict). The question arising here is as follows: Whether, and to what extent, stakeholder expectations are consistent with the objectives of the project? To answer this question the compatibility scale $(C)$ is used (Figure 4$)$.

\begin{tabular}{|c|c|c|c|c|c|c|c|c|c|c|}
\hline 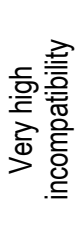 & 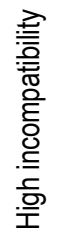 & 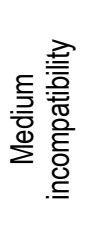 & 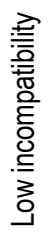 & 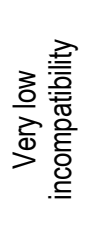 & $\begin{array}{l}\text { 음 } \\
\frac{.0}{\overline{0}} \\
\frac{0}{0} \\
\text { 은 }\end{array}$ & 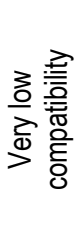 & 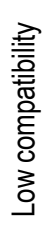 & 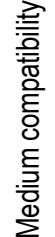 & 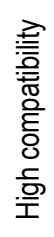 & 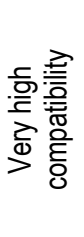 \\
\hline-5 & -4 & -3 & -2 & -1 & 0 & +1 & +2 & +3 & +4 & +5 \\
\hline \multicolumn{4}{|c|}{ Incompatibility } & \multicolumn{3}{|c|}{ Neutral } & \multicolumn{4}{|c|}{ ility } \\
\hline
\end{tabular}

Figure 4 - Diagram of the compatibility scale (C)

Sources: developed by the author

In the second dimension, the score is formulated in three steps. First, the procedure uses the method of AHP. The following question is asked here: Which of the stakeholders has more powerful tools to influence the project? Pairwise comparisons and Saaty's scale are used here (Figure 5).

\begin{tabular}{|c|c|c|c|c|c|c|c|c|}
\hline 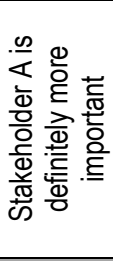 & 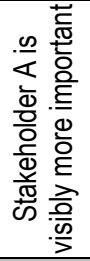 & 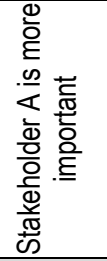 & 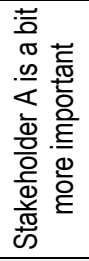 & 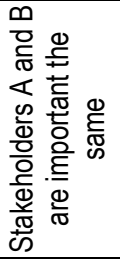 & 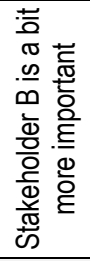 & 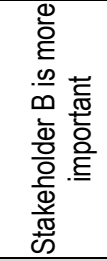 & 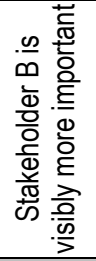 & 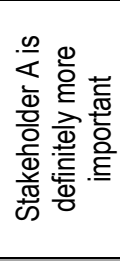 \\
\hline 9 & 7 & 5 & 3 & 1 & 3 & 5 & 7 & 9 \\
\hline \multicolumn{3}{|c|}{ Stakeholder $\mathrm{A}$ is more important } & \multicolumn{3}{|c|}{ Neutral } & \multicolumn{3}{|c|}{ Stakeholder $B$ is more important } \\
\hline
\end{tabular}

Figure 5 - Diagram of Saaty's scale

Sources: developed by the author

The responses established an initial assessment of the significance of the stakeholder, which is referred to as global weight (WG) [27]. Values here are in the range $W G \in\langle 0 ; 1\rangle$. Therefore, it requires 
conversion to the tool influence scale $(\mathrm{T})$. For this, the standardization for the maximum is used. Transformation is carried out by the formula (2).

$$
\mathrm{I}_{\mathrm{i}}=\frac{\mathrm{WG}_{\mathrm{i}}}{\mathrm{WG}_{\max }} \times 5
$$

The interpretation of the values obtained for the scale of influence is shown in Figure 6.

\begin{tabular}{|c|c|c|c|c|c|}
\hline No tools & Very week tools & Week tools & $\begin{array}{c}\text { Medium impact } \\
\text { tools }\end{array}$ & Strong tools & Very strong tools \\
\hline 0 & +1 & +2 & +3 & +4 & +5 \\
\hline
\end{tabular}

Figure 6 - Diagram of the tools influence scale (T)

Sources: developed by the author

The third dimension of the evaluation of the impact of a stakeholder concerns a readiness to actively influence the course of the project. Here the following question was asked: What is the probability that the stakeholder will take action in relation to the project? The probability scale (P)is used here, indicating the probability intervals determined for each value on the scale (Figure 7).

\begin{tabular}{|c|c|c|c|c|c|}
\hline $\begin{array}{c}\text { Not probable } \\
0 \%\end{array}$ & $\begin{array}{c}\text { Very low } \\
\text { probability } \\
(0-20 \%)\end{array}$ & $\begin{array}{c}\text { Low probability } \\
(20-40 \%)\end{array}$ & $\begin{array}{c}\text { Medium } \\
\text { probability } \\
(40-60 \%)\end{array}$ & $\begin{array}{c}\text { High probability } \\
(60-80 \%)\end{array}$ & $\begin{array}{c}\text { Very high } \\
\text { probability } \\
(80-100 \%\rangle\end{array}$ \\
\hline 0 & +1 & +2 & +3 & +4 & +5 \\
\hline
\end{tabular}

\section{Figure 7 - Scheme of the probability scale (P)}

Sources: developed by the author

Receiving the results of the analysis are the starting point for assessing scenarios for the implemented project.

Scenario analysis. Four basic scenarios were defined based on the stakeholder analysis: Realistic $\left(\mathrm{SC}_{\mathrm{R}}\right)$, Optimistic $\left(\mathrm{SC}_{\mathrm{O}}\right)$, Pessimistic $\left(\mathrm{SC}_{\mathrm{P}}\right)$ and Deterministic $\left(\mathrm{SC}_{\mathrm{D}}\right)$. Their characteristics are shown in Table 4.

Table 4 - Scenario characteristics

\begin{tabular}{|c|c|l|}
\hline Scenario & CSS $^{*}$ & \multicolumn{1}{c|}{ Description } \\
\hline $\mathrm{SC}_{\mathrm{R}}$ & $\mathbf{P} \geq 3$ & $\begin{array}{l}\text { The scenario involving the interaction of stakeholders whose probability measure } \\
\text { at least average }\end{array}$ \\
\hline $\mathrm{SC}_{\mathrm{O}}$ & $\mathbf{C} \geq 3$ & $\begin{array}{l}\text { The scenario involving the interaction of stakeholders for which compliance with } \\
\text { the expectations regarding the objectives of the project is positive and at least at a } \\
\text { medium level }\end{array}$ \\
\hline $\mathrm{SC}_{\mathrm{P}}$ & $\mathbf{C} \leq-3$ & $\begin{array}{l}\text { The scenario involving the interaction of stakeholders for which compliance with } \\
\text { the expectations regarding the objectives of the project is negative and maximum } \\
\text { at medium level }\end{array}$ \\
\hline $\mathrm{SC}_{\mathrm{D}}$ & $\mathrm{T} \geq 3$ & $\begin{array}{l}\text { The scenario involving stakeholders for which the measure of tools strength is at } \\
\text { least at the medium level }\end{array}$ \\
\hline
\end{tabular}

${ }^{*}$ CSS - criterion for stakeholders selection

Sources: developed by the author 
The impact of scenario (SC) is calculated by summing up the impact of all stakeholders included. Herein the formula used (3).

$$
I(S C)=\sum_{i=1}^{n} I_{i}
$$

In response to the identified scenarios, three general types of reactions are proposed:

- supporting $\left(R_{s}\right)$ - supporting allies, encouraging them to get involved in the project;

- minimization $\left(\mathrm{R}_{\mathrm{M}}\right)$ - weakening enemies, discouraging them to take negative actions, modifying the project's objectives in terms of taking into account their expectations;

- acceptation $\left(R_{A}\right)$ - accepting the scenario and the resignation of the impact on the stakeholders.

The above-described procedure was used as a test in the preparation for the reorganization project in one of the local governments in Poland. The next part of this paper presents brief information on the project and the results of the research achieved. Example of stakeholder analysis during a reorganization project in the local government institution. Short description of the local government. The study was conducted in one of the municipalities in south-eastern Poland, in preparation for the implementation of the Document Management System (DMS).

The project involves the implementation of both information technology and procedures necessary to move the municipal office and subordinate organizational units to a fully electronic workflow. It will have a significant impact on the functioning of workers in the studied organization and the quality of customer service. Funding for the project comes from European Union funds. Summary of the stakeholder analysis. A stakeholder analysis was carried out by a group of three experts selected by the audited organization. Aggregation assessments were conducted during focus group interview mode arrangements. In Table 5 and 6 below, a short summary of their research is presented.

Table 5 - Assessment of stakeholders groups

\begin{tabular}{|l|c|c|c|c|l|c|c|c|c|}
\hline \multicolumn{1}{|c|}{ Stakeholder } & C & T & P & I & \multicolumn{1}{c|}{ Stakeholder } & C & T & P & I \\
\hline Top management & 4 & 5 & 5 & 125 & Customers & 4 & 3 & 2 & 24 \\
\hline Linear managers & -3 & 4 & 3 & -36 & Suppliers & 3 & 3 & 3 & 27 \\
\hline Project managers & -1 & 2 & 2 & -4 & Subcontractors & 5 & 4 & 5 & 100 \\
\hline PMO staff & 3 & 4 & 4 & 48 & Supervisory institutions & 4 & 5 & 5 & 100 \\
\hline Ordinary workers & -4 & 3 & 2 & -24 & Cooperating organizations & 3 & 1 & 3 & 9 \\
\hline Project team & 5 & 5 & 5 & 125 & Competing organizations & -1 & 1 & 2 & -2 \\
\hline
\end{tabular}

Sources: developed by the author

The chosen types of reaction on stakeholder influence should be included in the project plan. Consequently, after the stakeholder analysis, it is necessary to prepare a schedule and a budget on the tasks which are the amplification of each type of reaction.

Table 6 - Scenario characteristics

\begin{tabular}{|c|c|c|}
\hline Scenario & (SC) & Reaction $(R)$ \\
\hline$S_{D}$ & 464 & \multirow{3}{*}{$\begin{array}{l}\text { Rs: reducing the negative impact of the project on the current efficiency of the organization, } \\
\text { testing the client's preferences and incorporating them to test DMS versions, taking into } \\
\text { account the motivation reward system for contractors working on the project }\end{array}$} \\
\hline $\mathrm{SC}_{\mathrm{R}}$ & 473 & \\
\hline $\mathrm{SC}_{0}$ & 533 & \\
\hline$S C_{P}$ & -60 & $\begin{array}{l}\text { RM: minimizing resistance from line managers and line employees by involving them in the } \\
\text { design process of the DMS and training }\end{array}$ \\
\hline
\end{tabular}

Sources: developed by the author 
Conclusions and directions of further researches. The proposed approach to the stakeholder analysis constitutes a development of methods commonly used in Project Management. The separation of the three dimensions and the use of the AHP method increases the precision of the analysis. Linking stakeholder analysis with the analysis of the scenario allows for a more accurate clarification of aftercare and support tasks. This can significantly improve the quality in the management of a project. Therefore, the research and the paper provide the practical output.

Moreover, the developed methodological assumptions enrich both the method of Project Management and the method of AHP. In this respect, a theoretical effect is established. It gives other directions of development for the mentioned methods.

In the near future, an in-depth analysis of the impact of sources of stakeholder influence on a project is planned with respect to this study. This will require expanding the Stakeholders Structure Model with the addition of a level containing the identified seven tools of influence.

\section{References}

1. G. Gereffi, "The global economy: organization, governance, and development," The handbook of economic sociology, 2, pp.160-182, 2005.

2. J. Urry, "The complexity turn," Theory Culture and Society 22, no. 5, pp. 1-14, 2005.

3. J. P Walsh, A.D. Meyer, and C. B. Schoonhoven. "A future for organization theory: Living in and living with changing organizations," Organization Science 17, no. 5, pp. 657-671, 2006.

4. R. Huggins, H. Izushi, and P. Thompson. "Regional competitiveness: Theories and methodologies for empirical analysis," The Business and Economics Research Journal, 6, no. 2, pp. 155-172, 2013.

5. R.K. Smollan, "The multi-dimensional nature of resistance to change," Journal of Management \& Organization, 17, no. 6: pp. 828-849, 2011.

6. B.S. Kuipers, M. Higgs, W. Kickert, L. Tummers, J. Grandia, and J. Van der Voet. "The management of change in public organizations: A literature review," Public Administration, 92, no. 1, pp. 1-20, 2014.

7. Organizational Competence Baseline - The standard for moving organizations forward, Zurich: IPMA, 2013, p. 16

8. A Guide to the Project Management Body of Knowledge (PMBOK® Guide), 5th Edition. Pennsylvania: PMI, 2013, p. 3.

9. F. C. Lunenburg, "Approaches to managing organizational change," International Journal of Scholarly Academic Intellectual Diversity, 12, no. 1, pp. 1-10, 2010.

10. B. Zarei, M. Ehsan and A. Ghapanchi, "Project process reengineering (PPR): a BPR method for projects," International Journal of Information Systems and Change Management 4, no. 4, pp. 299-313, 2010.

11. M. M. Crossan and M. Apaydin, "A multi-dimensional framework of organizational innovation: A systematic review of the literature," Journal of Management Studies, 47(6), pp. 1154-1191, 2010.

12. Oslo manual. Guidelines for collecting and interpreting innovation data, 3d Edition, Paris: OECD Publications, $2005,17$.

13. T. Robyn, and C. Hardy, "Reframing resistance to organizational change," Scandinavian Journal of Management, 27 no. 3, pp. 322-331, 2011.

14. D. G. Erwin, and A. N. Garman. "Resistance to organizational change: linking research and practice," Leadership \& Organization Development Journal, 31, no. 1, pp. 39-56, 2010.

15. K. Kozioł, „Analiza strategiczna przedsiębiorstwa na poziomie makrootoczenia,” Zeszyty Naukowe Uniwersytetu Szczecińskiego. Studia i Prace Wydziału Nauk Ekonomicznych i Zarządzania, 17, pp. 77-88, 2010.

16. S. M. Sanderson, and G. A. Luffman. "Strategic planning and environmental analysis," European Journal of Marketing, 22, no. 2, pp. 14-27, 1988 .

17. H. Weihrich, "The TOWS matrix - a tool for situational analysis," Long range planning, 15(2), pp. 54-66, 1982.

18. G. Gierszewska and M. Romanowska, Analiza strategiczna przedsiębiorstwa, Warsaw: PWE, 1998, pp. 35-55.

19. T. Donaldson, and L. E. Preston, "The stakeholder theory of the corporation: Concepts, evidence, and implications," Academy of Management Review, 20 no. 1, pp. 65-91, 1995.

20. R.E. Freeman, Strategic management: A stakeholder approach. Cambridge: Cambridge University Press, 2010.

21. M. Morsing, and M. Schultz, "Corporate social responsibility communication: stakeholder information, response and involvement strategies," Business Ethics: A European Review, 15 no. 4, pp. 323-338, 2006.

22. Elias, R. Y. Cavana, and L. S. Jackson, "Stakeholder analysis for R\&D project management," R\&D Management, 32 vol. 4, pp. 301-310, 2002.

23. J. Frooman, "Stakeholder influence strategies,", Academy of Management Review, 24 no. 2, 191-205, 1999.

24. T.L. Saaty The Analytic Hierarchy Process, New York: McGraw-Hill, 1980. 
25. T. L. Saaty, "Decision making with the analytic hierarchy process," International Journal of Services Sciences, 1, , pp. 83-98, 2008.

26. Prusak and P. Stefanów, Analityczny proces hierarchiczny, Warsaw: C.H. Beck, 2014.

27. Prusak, A., J. Strojny, and P. Stefanow, "Analityczny proces hierarchiczny (AHP) na skróty-kluczowe pojęcia i literatura", Humanities and Social Sciences, 19/21, vol. 4, pp. 179-192, 2014.

Я. Стройні, D.Sc., доцент, Ржешовский технологічний університет (Польща);

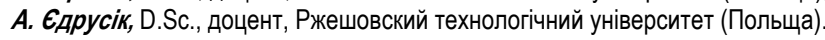

Стейкхолдерський аналіз проектів реорганізації в органах місцевого самоврядування: інновації в менеджменті

Аналіз стейкхолдерів проекту $\epsilon$ одним із важливих елементів забезпечення його ефективної реалізації. Автори наголошують, що даний аспект є вирішальним для високоризикованих проектів, таких як реорганізація. Автори визначають, що залучення широкого кола працівників до реалізації проекту, комунікації з постачальниками та клієнтами - це не тільки потенційні джерела ризику, але й певні можливості. Тому успіх реорганізації в першу чергу залежить від якості проведеного аналізу стейкхолдерів даного процесу. У статті авторами використано стейкхолдерський аналіз. Результати дослідження свідчать про наявність різних науково-методичних підходів до формування принципів ефективного управління проектами (наприклад, IPMA ICB 4.0). В основному всі концепції засновані на традиційній та спрощеній оцінці впливу стейкхолдерів на процес реалізації проекту. При цьому високоризиковані проекти вимагають більш глибшого стейкхолдерського аналізу. Авторами запропоновано підхід до проведення стейкхолдерського аналізу, виокремлено основні етапи прийняття управлінських рішень. Запропоновану методологію було перевірено під час реального проекту реорганізації в одному з польських органів місцевого самоврядування. У статті проведено аналіз наукової літератури з точки зору оцінки діяльності зацікавлених сторін в реорганізації польського органу місцевого самоврядування. Для ідентифікації та структуризаціі стрейкхолдерів було використано процедуру методу АНР (Аналітичний процес ієрархії). Отримані результати стали основою для оцінки статистичної значимості впливу стейкхолдерів на процес реорганізації, що визначалась за допомогою шкали Сааті. Було запропоновано нову шкалу для оцінки узгодженості очікувань стейкхолдерів з цілями проекту, а також впливом стейкхолдерів на проект. Практична апробація розробленого методу спровокувала підвищення робочого навантаження, оскільки аналіз стейкхолдерів потребує процесу прийняття та узгодження рішень угрупі, що реалізує проект. Крім того, члени команди проекту повинні мати відповідні знання щодо особливостей методу АНР. Окрім цього практична апробація дозволила точніше ідентифікувати стейкхолдерів та виокремити ї роль у проекті.

Ключові слова: проект, реорганізація, аналіз зацікавлених сторін, стейкхолдер, організація, місцеве самоврядування, державне управління.

Manuscript received: 03.10.2018

(C) The author(s) 2018. This article is published with open access at Sumy State University. 